\title{
Effects of Cropping Systems on Soil Properties and Enzymatic Activities in Calcareous Soil
}

\author{
Vivek Kumar ${ }^{1}$, Sanjay Kumar Singh ${ }^{1 *}$, Pankaj Singh ${ }^{2}$, Sanjay Tiwari², \\ Mani Mesha Nand ${ }^{2}$, Kumar Chiranjeeb ${ }^{2}$ and Munmun Majhi ${ }^{3}$
}

${ }^{1}$ Department of Soil Science, Dr. Rajendra Prasad Central Agricultural University, Pusa, Dholi Campus, Muzaffarpur- 843121, Bihar, India

${ }^{2}$ Department of Soil Science, Dr. Rajendra Prasad Central Agricultural University, Pusa- 848125, Bihar, India

${ }^{3}$ Department of Soil Science \& Agricultural Chemistry, Uttar Banga Krishi Viswavidyalaya, Cooch Behar, W.B-736165, India

*Corresponding author

\section{A B S T R A C T}

\begin{tabular}{|c|}
\hline Keywords \\
\hline $\begin{array}{l}\text { Cropping system, } \\
\text { Soil quality, } \\
\text { Dehydrogenase, } \\
\text { Muzaffarpur, } \\
\text { Pegionpea }\end{array}$ \\
\hline Article Info \\
\hline $\begin{array}{l}\text { Accepted: } \\
10 \text { March } 2020 \\
\text { Available Online: } \\
10 \text { April } 2020\end{array}$ \\
\hline
\end{tabular}

The organic matter is one of the important soil quality attribute can have beneficial effects on soil quality because organic matter is related to soil physico-chemical properties and availability of nutrients to crop. The present investigation was carried out during 2017-18 at research farm of Tirhut College of Agriculture, Dholi, Muzaffarpur to evaluate the effect of cropping system on soil properties and enzymatic activities in calcareous soils. For the study, soil samples were collected from each treatment (cropping systems) during mid-April to mid-May, 2018 after completion of one cropping cycle for the analysis of soil properties using standard procedure. The variability in soil $\mathrm{pH}$ under different cropping systems at surface layer ranged from 7.79 to 8.79 . However, highest 8.81 and lowest soil $\mathrm{pH} 7.85$ was recorded under different cropping systems at sub-surface layer. The carbon stock in different cropping systems varied from 6.98 to $11.95 \mathrm{t} \mathrm{ha}^{-1}$ and 4.89 to $10.81 \mathrm{t} \mathrm{ha}^{-}$ ${ }^{1}$ in surface and sub-surface soil layer under different cropping systems. The dehydrogenase and alkaline phosphatase enzymes variation observed from 6.87 to $19.91 \mu \mathrm{g}$ TPF g $\mathrm{g}^{-1}$ soil $24 \mathrm{~h}^{-1}$ and 6.77 to $33.55 \mu \mathrm{g}$ PNP $\mathrm{g}^{-1}$ soil $^{-1}$ at the $0-15 \mathrm{~cm}$ soil depth in which pigeon pea cropping system obtained higher dehydrogenase and alkaline phosphatase enzymes than others kinds od cropping systems.

\section{Introduction}

The crop rotations primarily rice-wheat and maize-wheat cropping system in the IndoGangatic Plains of India has caused nutrient imbalance, soil degradation, and due to intensification of crops may deteriorate the soil quality (Ladha et al., 2003; Chauhan et al., 2012). However, the long-term inclusion of pulses in maize-wheat rotation improved the soil fertility, subsequently increased the crop nutrient acquisition and crop 
productivity (Venkatesh et al., 2017). The organic matter quality and quantity can have beneficial effects on soil quality because organic matter is related to aggregation, soil structure, and water infiltration and availability of nutrients to crop. Noncultivated land, the type of vegetative cover is a factor influencing the soil organic carbon content (Liu et al., 2010).

Bulk density (BD) is a major factor of soil compaction which influenced by intense operation of heavy machinery and implements in the field causes soil compaction which may increase bulk density and reduce the transportation of water and air through the soil. Soil aggregates are also an important physical character which helps to facilitate a good soil structure. Significant improvement in carbon dioxide evolution and dehydrogenase at two soil depths were recorded as a consequence of green manuring with both Sesbania species and incorporation of mungbean residue in rice-wheat cropping system (Datt and Sharma 2006).

Soil enzymes activities and microbial biomass have an important influence on nutrient cycling to sustain the soil fertility index (Ullah et al., 2013).The microbial and enzyme activities of the soil are closely related to the organic matter content and influenced by hydrothermal regimes of the soil (Bhavya et al., 2018). The activity of soil phosphatases can be influenced by numerous factors, and soil properties and farming systems play a key role among them. Considering the above facts, the present study was aimed to evaluate the effect of cropping systems on soil properties and enzymatic activities in calcareous soils.

\section{Materials and Methods}

The present investigation was carried out during 2017-18 at research farm of Tirhut
College of Agriculture, Dholi, Muzaffarpur a campus of Dr. Rajendra Prasad Central Agricultural University, Pusa, Bihar under different cropping pattern on same piece of land more than five years. Each crop was grown with normal cultural practices and recommended dose of fertilizer. The Dholi campus is situated on the southern bank of the river Burhi Gandak at an elevation of 52.18 meter above mean sea level and intersected by $25.98^{\circ} \mathrm{N}$ latitude and $85.60^{\circ} \mathrm{E}$ longitude. It has semi- arid, sub-tropical climate with hot dry summer, moderate rainfall and cool winter season. The research sites representing upland and fairly uniform in topography and the soil was deep, well drained and calcareous alluvium soil, mostly alkaline in reaction.

For the study, the soil samples were collected from each treatment (cropping system) during mid-April to mid-May, 2018 after completion of one cropping cycle for the analysis of soil physico-chemical properties. Each cropping systems were represented by three plots with area $5 \times 5 \mathrm{~m}$. and the total of 27 (9 cropping system x 3 plots) samples were collected in replications then it brought into laboratory.

The processed soil samples were taken for analysis of soil parameters used prescribed standard parameters (Jackson, 1973). The soil organic stock was calculated by soil organic carbon $(\%)$ x bulk density $\left(\mathrm{Mg} \mathrm{m}^{-3}\right) \times$ depth (cm)expressed in $\mathrm{t} \mathrm{ha}^{-1}$.

The activity of (alkaline) phosphatase was assayed by using standard method described by Tabatabai and Bremner (1969). Dehydrogenase activity was assayed by quantifying the 2,3,5-triphenyl formazon (TPF) produced and expressed as mg TPF produced $\mathrm{g}^{-1}\left(24 \mathrm{~h}^{-1}\right)$ as described by Cassida et al., (1964). Analysis of variance (ANOVA) enunciated by Fisher (1938) was followed to calculated the nature and magnitude of treatment effects revealed by ' $F$ '-test. 


\section{Results and Discussion}

The variability in soil $\mathrm{pH}$ under different cropping systems at surface layer ranged from 7.79 to 8.79. However, highest 8.81 and lowest soil pH 7.85 was recorded under different cropping systems at sub-surface layer. The rice-wheat cropping system exhibited lowest soil $\mathrm{pH}$ (7.79) followed by pigeon pea cropping system might be attributed to submergence of soil during rice cultivation and greater amount of leaf litters deposited in pigeonpea field shown in figure 1 $\& 2$.

The comparable decrement in soil $\mathrm{pH}$ was noticed in rice-wheat $(12.84 \%)$ and pigeonpea cropping system (11.54\%) over maizemaize cropping system contained highest soil $\mathrm{pH}$ (8.79) and it was found statistically significant (Trehan et al., 2001).

The effect of cropping system on electrical conductivity $\left(\mathrm{dSm}^{-1}\right)$ depicted in figure $1 \& 2$. The variability in electrical conductivity ranged from 2.54 to $1.16 \mathrm{dSm}^{-1}$ and 1.14 to $2.37 \mathrm{dSm}^{-1}$ salt concentration at surface layer $(0-15 \mathrm{~cm})$ and sub-surface layer (15$30 \mathrm{~cm}$ )soil depth. It was found higher in ricepotato cropping system at surface soil and onion and potato in sub-surface soil. The soil and crop management practices and organic matter content may influence the variability in salts concentration. The salt concentration observed reduces with soil depth depicted in figure $1 \& 2$. The concentration of total soluble salts found in desirable range which was found less than $2 \mathrm{dSm}^{-1}$ under cropping systems except onion-garlic cropping systems. The variation was found might be due to cropping system irrespective of electrical conductivity and it was found statistically significant. The organic carbon content under different cropping systems ranged from 0.33 to $0.63 \%$ at $0-15 \mathrm{~cm}$ soil depth given in the figure 3 . The highest organic carbon content $(0.63 \%)$ was noticed in pigeonpea cropping system followed by mustard moongbean $(0.62 \%)$, pigeon pea $(0.61 \%)$ and rice-wheat $(0.55 \%)$ at surface soil layer. The legume crops contributing more organic matter maintained good quality of soil.

The fallow land contained the minimum quantity $(0.33 \%)$ of organic carbon. The distribution of soil organic matter reported decline with the soil depth and found comparatively less as compared to surface soil. The pigeon pea based system, the fallen leaves and root mass undergo decompose and improve the soil structure through enrichment of the organic content (Singh et al., 2012) (Fig. 4). The carbon stock in different cropping systems varied from 6.98 to $11.95 \mathrm{t}$ $\mathrm{ha}^{-1}$ and 4.89 to $10.81 \mathrm{t} \mathrm{ha}^{-1}$ in surface and subsurface soil layer under different cropping systems. Higher carbon stock was found in the surface and sub-surface soil layer under maize-maize cropping system than pigeonpea. The lowest carbon carbon stock was found in fallow land depends upon the organic carbon and bulk density. Bulk density was recorded greater in the fallow land than the rest of the cropping systems as given in the figure 5 .

The variability in Cation Exchange Capacity ranged from 16.66 to $28.62\left(\mathrm{Cmol}\left(\mathrm{P}^{+} \mathrm{kg}^{-1}\right)\right.$ reveals in figure 6 contained higher cation exchange capacity $\left(\mathrm{Cmol} \mathrm{P}^{+} \mathrm{kg}^{-1}\right)$ in moongbean. This resulted in high variability of cation exchange capacity $\left(\mathrm{Cmol} \mathrm{P}^{+} \mathrm{kg}^{-1}\right)$ among the cropping systems may be attributed to organic carbon content. The dehydrogenase and alkaline phosphatase enzymes showed significant changes under different cropping systems depicted in figure $7 \& 8$. The dehydrogenase and alkaline phosphatase enzyme showed variation from 6.87 to $19.91 \mu \mathrm{g} \mathrm{TPF} \mathrm{g}{ }^{-1}$ soil $24 \mathrm{~h}^{-1}$ and 6.77 to $33.55 \mu \mathrm{g}$ PNP $\mathrm{g}^{-1}$ soil $\mathrm{h}^{-1}$ at the upper surface layer, respectively (Table 1 and 2). 
Table.1 The geographic coordinates of nine locations under cropping system

\begin{tabular}{|c|c|c|c|c|c|}
\hline Sl. No. & Treatments & Cropping systems & Latitude & Longitude & Range \\
\hline 1. & $\mathrm{~T}_{1}$ & Onion-garlic & $25^{0} 59^{\prime} 44.73^{\prime} \mathrm{N}$ & $85^{0} 35^{\prime} 50.86^{\prime} \mathrm{E}$ & $366 \mathrm{~m}$ \\
\hline 2. & $\mathrm{~T}_{2}$ & Tuber -Mungbean & $25^{0} 59^{\prime} 39.55^{\prime} \mathrm{N}$ & $85^{\circ} 36^{\prime} 03.28^{\prime} \mathrm{E}$ & $829 m$ \\
\hline 3. & $\mathrm{~T}_{3}$ & Pigeon Pea & $25^{0} 59^{\prime} 35.68^{\prime} \mathrm{N}$ & $85^{\circ} 35^{\prime} 43.19^{\prime} \mathrm{E}$ & $365 \mathrm{~m}$ \\
\hline 4. & $\mathrm{~T}_{4}$ & Rice-Potato & $25^{0} 59^{\prime} 43.58^{\prime} \mathrm{N}$ & $85^{\circ} 35^{\prime} 43.29^{\prime} \mathrm{E}$ & $853 m$ \\
\hline 5. & $\mathrm{~T}_{5}$ & Mustard-Mungbean & $25^{0} 59^{\prime} 37.67^{\prime} \mathrm{N}$ & $85^{\circ} 36^{\prime} 80.48^{\prime} \mathrm{E}$ & $1083 \mathrm{~m}$ \\
\hline 6. & $\mathrm{~T}_{6}$ & Turmeric-Mungbean & $25^{0} 59^{\prime} 36.65^{\prime} \mathrm{N}$ & $85^{\circ} 36^{\prime} 27.94^{\prime} \mathrm{E}$ & $828 \mathrm{~m}$ \\
\hline 7. & $\mathrm{~T}_{7}$ & Fallow land & $25^{0} 59^{\prime} 30.59^{\prime} \mathrm{N}$ & $85^{0} 35^{\prime} 57.36^{\prime} \mathrm{E}$ & $2785 \mathrm{~m}$ \\
\hline 8. & $\mathrm{~T}_{8}$ & Rice-Wheat & $25^{0} 59^{\prime} 41.53^{\prime} \mathrm{N}$ & $85^{\circ} 36^{\prime} 80.43^{\prime} \mathrm{E}$ & $1428 \mathrm{~m}$ \\
\hline 9. & $\mathrm{~T}_{9}$ & Maize-Maize & $25^{0} 59^{\prime} 33.83^{\prime} \mathrm{N}$ & $85^{0} 36^{\prime} 14.29^{\prime} \mathrm{E}$ & $1080 \mathrm{~m}$ \\
\hline
\end{tabular}

Table.2 Correlation among soil properties and soil enzymes

\begin{tabular}{|c|c|c|c|c|c|c|}
\hline & $\begin{array}{l}\text { OC } \\
(\%)\end{array}$ & $\begin{array}{l}\text { Carbon } \\
\text { stocks } \\
\text { (t ha-1) }\end{array}$ & $\begin{array}{l}\text { CEC } \\
\text { Cmol } \\
\left(\mathbf{P}^{+}\right) / \mathbf{k g}\end{array}$ & $\begin{array}{l}\text { BD } \\
(\mathrm{Mg} \mathrm{m}-3)\end{array}$ & $\begin{array}{l}\text { Dehydrogenase } \\
(\mu \mathrm{g} \text { TPF g-1 } \\
24 \mathrm{~h}-1)\end{array}$ & $\begin{array}{l}\text { Alkaline Phosphatase } \\
\text { ( } \mu \text { g PNP g-1 soil h-1) }\end{array}$ \\
\hline $\mathrm{OC}(\%)$ & 1 & & & & & \\
\hline Carbon stocks (t ha-1) & 0.981 & 1 & & & & \\
\hline CEC & 0.943 & 0.932 & 1 & & & \\
\hline BD (Mg m-3) & -0.744 & -0.609 & -0.687 & 1 & & \\
\hline $\begin{array}{l}\text { Dehydrogenase } \\
(\mu \mathrm{g} \text { TPF g-1 24h-1) }\end{array}$ & 0.836 & 0.815 & 0.686 & -0.662 & 1 & \\
\hline $\begin{array}{l}\text { Alkaline Phosphatase } \\
\text { ( } \mu \text { g PNP g-1 soil h-1) }\end{array}$ & 0.694 & 0.638 & 0.530 & -0.738 & 0.846 & 1 \\
\hline
\end{tabular}

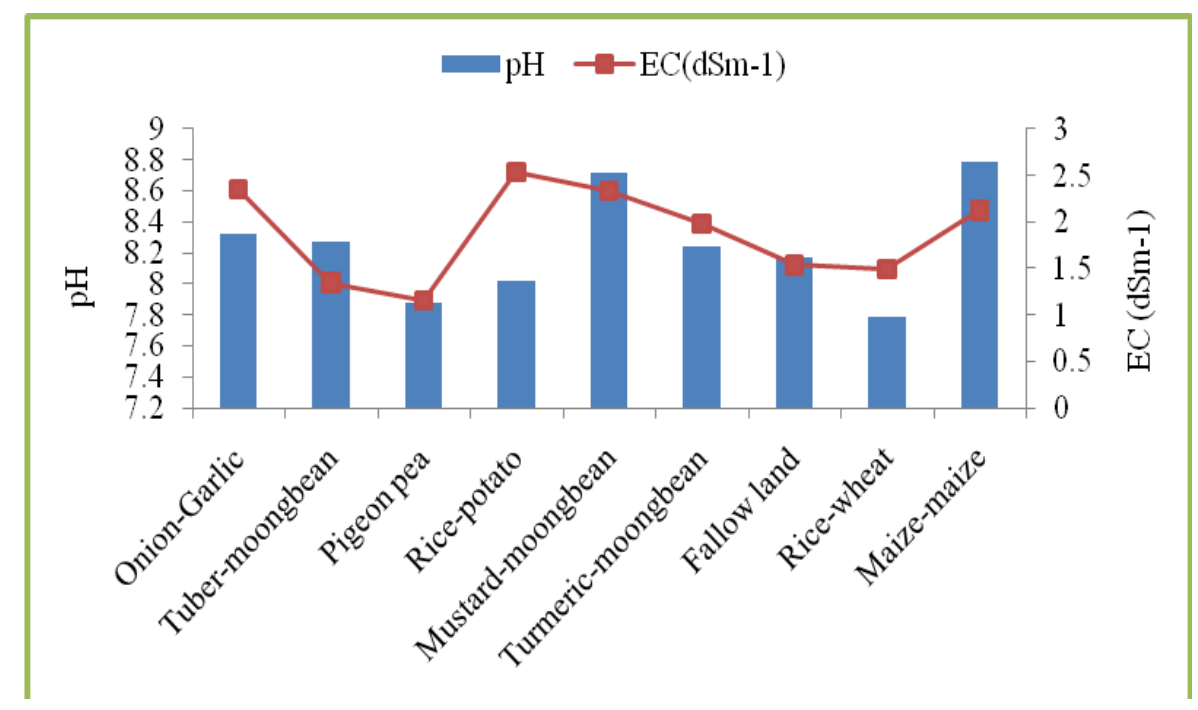

Fig.1 Effect of cropping systems on soil $\mathrm{pH}$ and electrical conductivity (dSm-1) at $0-15 \mathrm{~cm}$ soil depth 


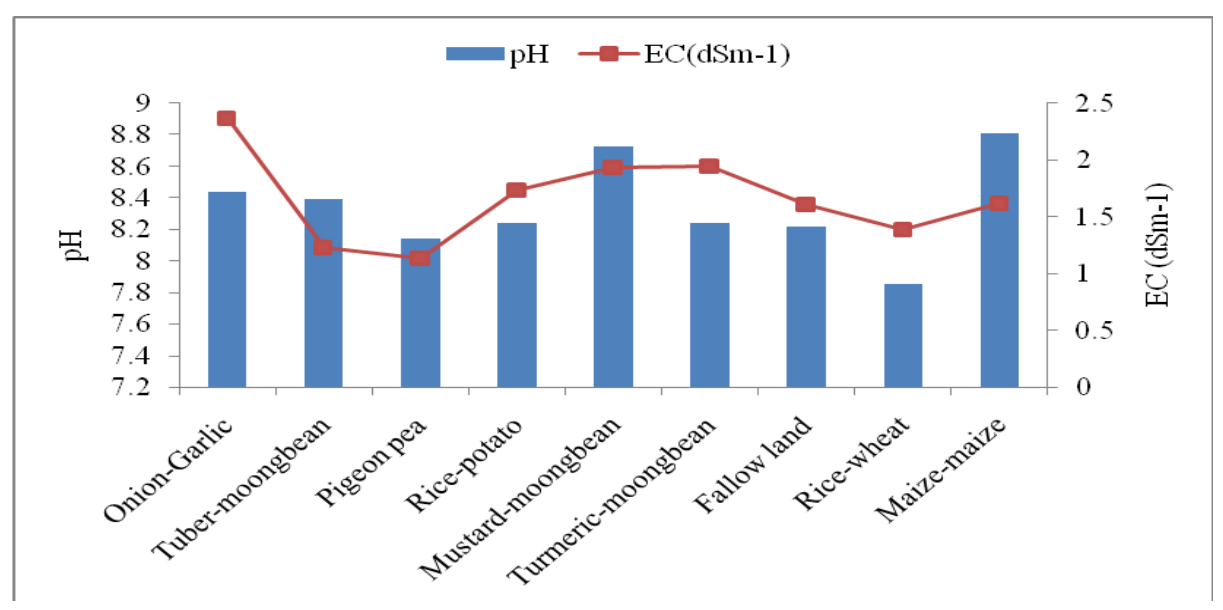

Fig.2 Effect of cropping systems on soil $\mathrm{pH}$ and electrical conductivity (dSm-1) at $15-30 \mathrm{~cm}$ soil depth

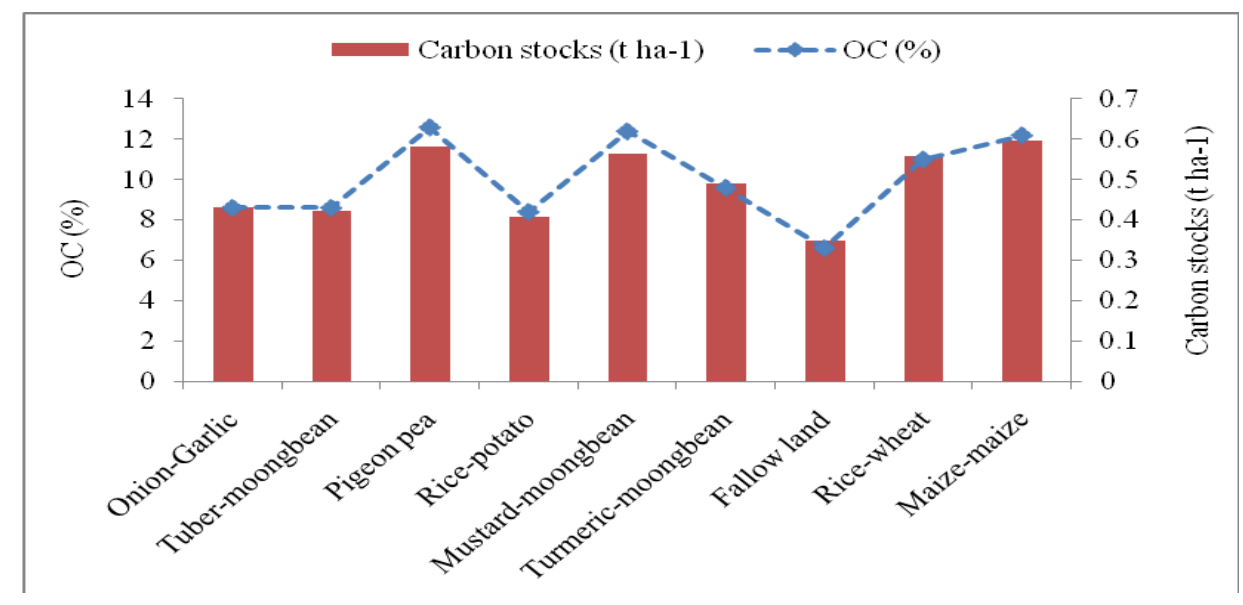

Fig.3 Effect of cropping systems on soil OC (\%) and Carbon stocks (t ha-1) at $0-15 \mathrm{~cm}$ soil depth

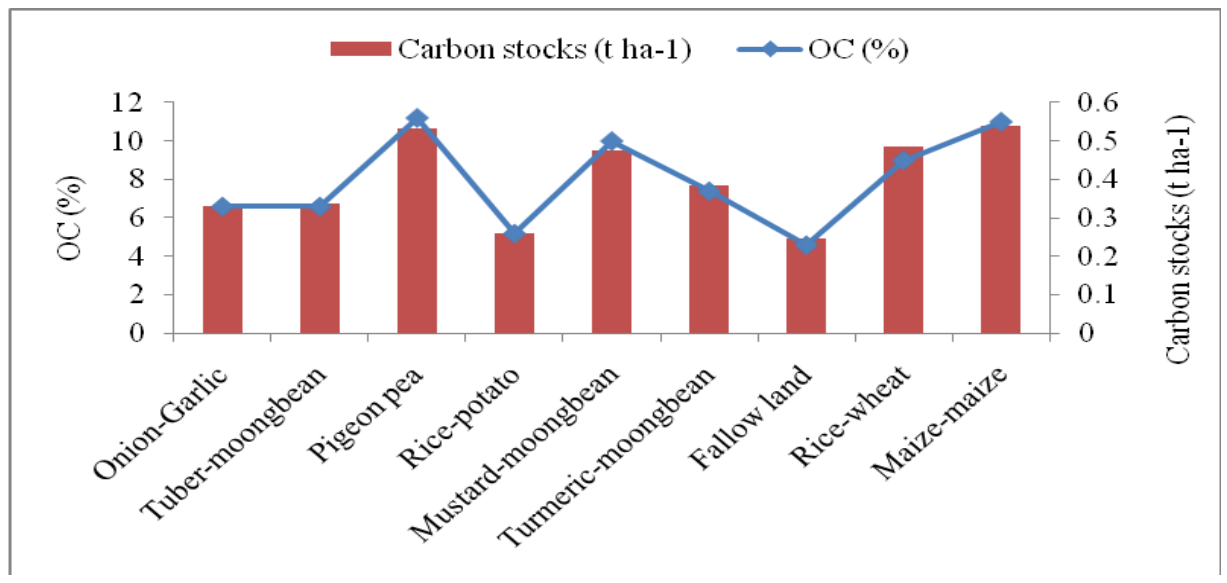

Fig.4 Effect of cropping systems on soil OC (\%) and Carbon stocks (t ha-1) at $15-30 \mathrm{~cm}$ soil depth 


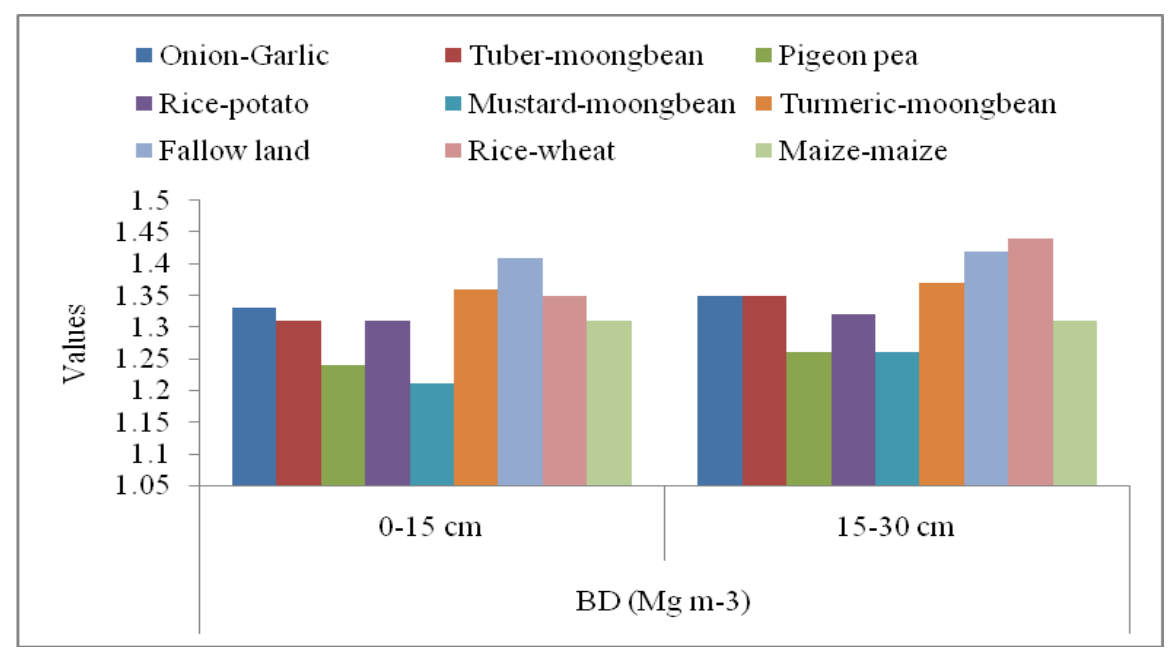

Fig.5 Effect of cropping system on soil bulk density at $0-15 \mathrm{~cm}$ and $15-30 \mathrm{~cm}$ soil depth

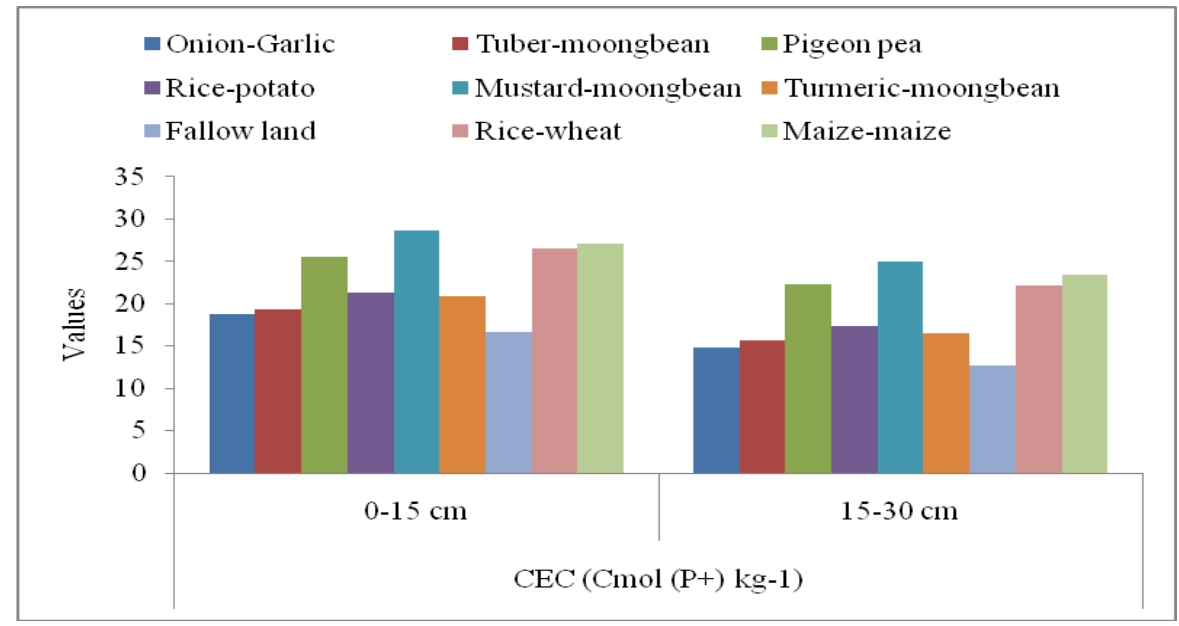

Fig.6 Effect of cropping system on soil CEC at $0-15 \mathrm{~cm}$ and $15-30 \mathrm{~cm}$ soil depth

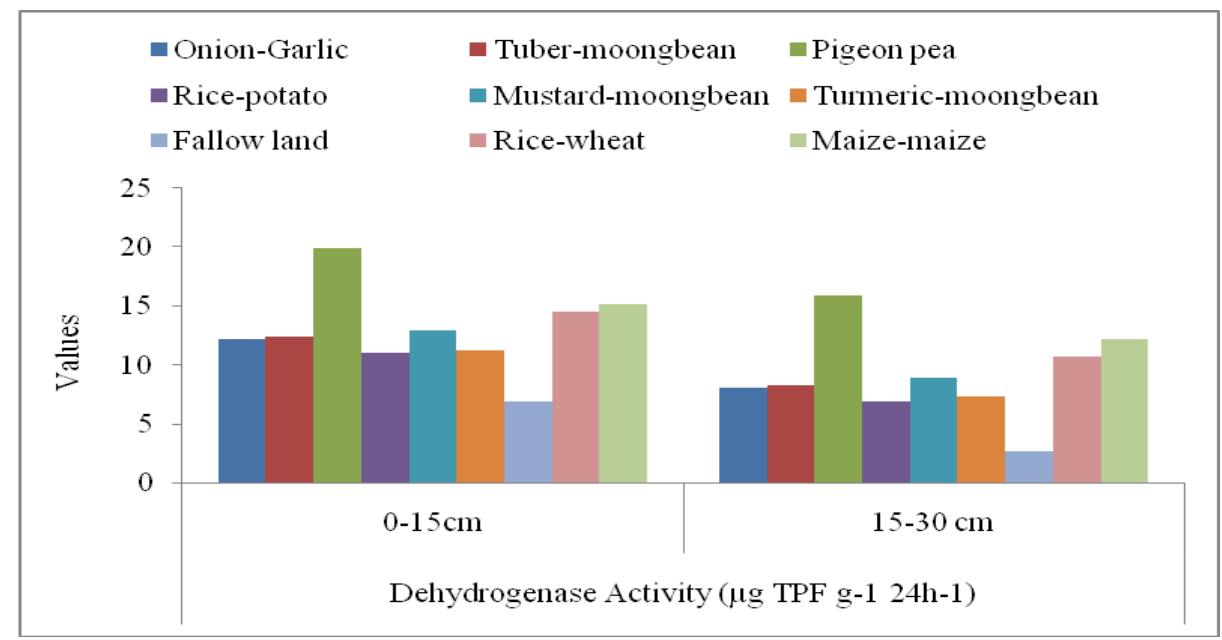

Fig.7 Effect of cropping system on soil dehydrogenase activity at 0-15and 15-30cm depth 


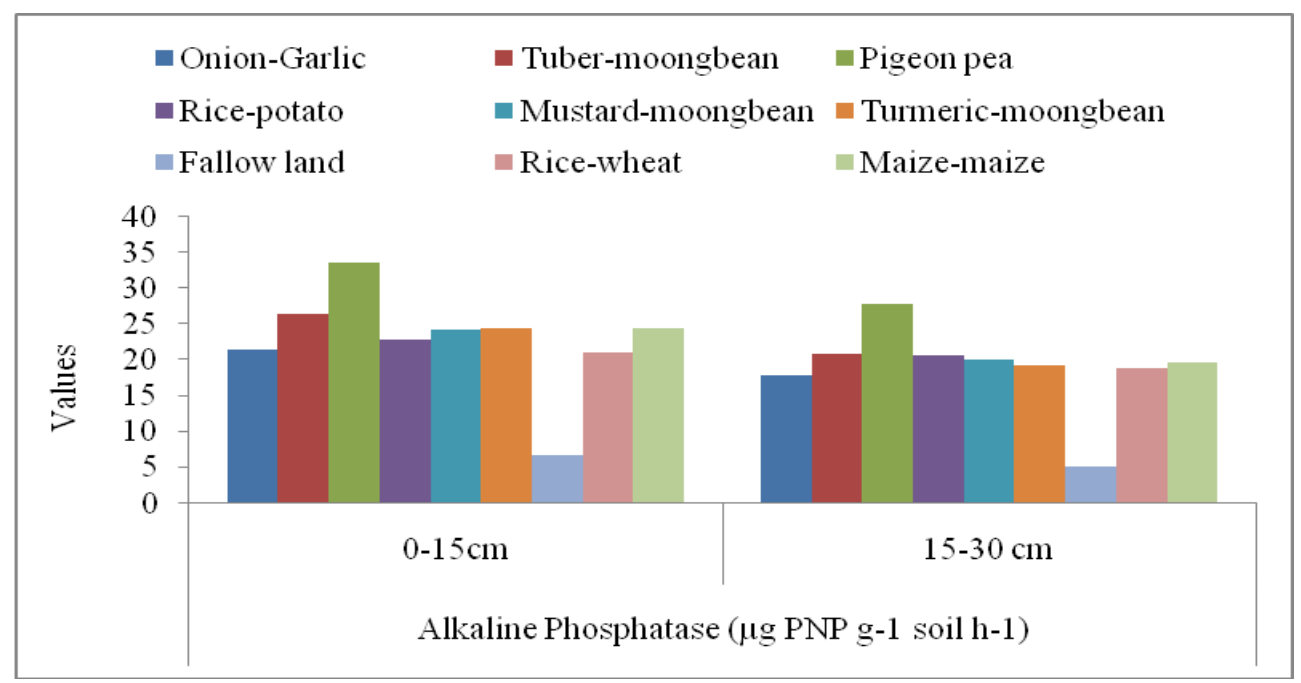

Fig.8 Effect of cropping system on soil Alkaline phosphatage activity at 0-15 and $15-30 \mathrm{~cm}$ soil depth

Among cropping systems, pigeon pea maintained higher amount of dehydrogenase and alkaline phosphatase enzymes in the soils than rest of the crop rotation, whereas, fallow land showed the lowest value. The observations on dehydrogenase and alkaline phosphatase enzymes showed variability in enzymatic activities with organic carbon.

Organic carbon is related to soil biological properties such as microbial biomass carbon and dehydrogenase activity (Kanchikerimath and Singh, 2000). The soil systems under cropping systems with the highest organic matter input tended to have the greatest dehydrogenase and alkaline phosphatase enzyme. The lowest dehydrogenase and alkaline phosphatase enzyme obtained in fallow land may be due to low organic carbon content.

A significant and positive correlation of dehydrogenase enzymes and phophatage enzymes was observed between organic carbon, carbon stock and cation exchange capacity whereas, the negative correlation of bulk density was found among the soil properties depicted in table 2 .

\section{References}

Bhavya V.P., Kumar S.A., Kiran S.K., Alur A., Shivakumar K.M., and Shivanna M.. 2018. Effect of Different Cropping System on Important Soil Enzyme Activity, Organic Carbon and Microbial Activity with Different Depth. International Journal of Current Microbiology and Applied sciences.2018; 7:315-322.

Casida L.E. Klien D.A. 1964. Sohotro T. Soil Dehydrogenase Activity. Soil Science. 1964; 3:71-76.

Chauhan B.S., Mahajan G., Sardana V., Timsina J. and M.L. 2012. Productivity and sustainability of ricewheat cropping system in the IndoGangatic Plains of the Indian subcontinent: problems, opportunities, and strategies. Advance Agronomy, 117: 315-369.

Jackson M.L. (1973) Soil Chemical Analysis. New Delhi, Prentice Hall, 48-302.

Kanchikerimath M. and Singh D. 2001. Soil organic matter and biological properties after 26 years of maizewheat-cowpea cropping as affected by manure and fertilisation in a Cambisol 
in semiarid region of India. Agriculture, Ecosystems and Environment. 82(2):155-162.

Ladha J.K., Pathak H., Tirol-Padre A., Dawe D. and Gupta RK. 2003. Productivity trends in intensive rice-wheat cropping system: issues and impact. Madison, Wisconsin: USA: Agronomy series ASA-CSSA-SSSA Publishers. p. 45-76.

Liu Xl., He Yq., Zhang H.L., Schroder J.K, Li Cl., Zhou J. and Zhang Z. ( 2010). Impact of land use and soil fertility on Distributions of soil aggregate fractions and some nutrients. Pedosphere. 20:666-673.

Singh A., Singh V.K., Chandra R. and Srivastava P.C. 2012. Effect of integrated nutrient management on pigeon pea-based intercropping system and soil properties in mollisols of the Tarai region. Journal of the Indian Society of Soil Science. 60: 3844.

Tabatabai M.A. 1994. Soil enzymes. p. 775-
833. In Weaver, R.W., et al., (eds.) Methods of soil analysis. Part 2. Microbiological and biochemical properties. Soil Science Society of America. Madison, Wisconsin, USA

Trehan S.P., Sharma R.C. and Sharma H.C. 2001. Long term effect of potato based systems, fertilizers and manures on properties of alluvial soil of Punjab. Journal of the Indian Potato Association. 28: 207-215.

Ullah R., Lone, M.I., Ullah K.S., Mehdi S.M. and Qazi M.A. 2013. Effect of cropping system and seasonal variation on soil microbial biomass and enzymatic activities in arid soils. Journal of Animal and Plant Sciences. 2013; 23:493-499.

Venkatesh M.S., Hazra K.K., Ghosh P.K., Praharaj C.S. and Kumar N. 2012.Long-term effect of pulses and nutrient management on soil carbon sequestration in Indo-Gangetic plains of India. Canadian journal of Soil Science. 93:127-136.

\section{How to cite this article:}

Vivek Kumar, Sanjay Kumar Singh, Pankaj Singh, Sanjay Tiwari, Mani Mesha Nand, Kumar Chiranjeeb and Munmun Majhi. 2020. Effects of Cropping Systems on Soil Properties and Enzymatic Activities in Calcareous Soil. Int.J.Curr.Microbiol.App.Sci. 9(04): 1255-1262. doi: https://doi.org/10.20546/ijcmas.2020.904.148 